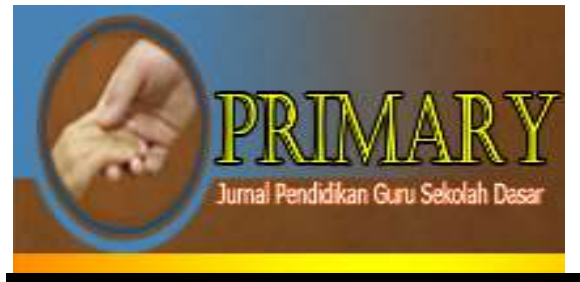

\author{
PRIMARY: JURNAL PENDIDIKAN GURU SEKOLAH DASAR \\ VOLUME 10 NOMOR 5 OKTOBER 2021 \\ ISSN : 2303-1514 | E-ISSN : 2598-5949 \\ DOI : http://dx.doi.org/10.33578/jpfkip.v10i5.8164 \\ https://primary.ejournal.unri.ac.id/index.php/JPFKIP
}

\title{
PARENTING STYLES IN SHAPING THE CHILDREN'S SOCIAL CARE CHARACTER DURING THE PANDEMIC
}

\author{
Sri Rizqi Hasanah ${ }^{1}$, Ristiyani ${ }^{2}$, Muhammad Noor Ahsin ${ }^{3}$ \\ 1,2,3 Universitas Muria Kudus, Indonesia \\ 1rizqihasanah503@gmail.com, ${ }^{2}$ ristiyani@umk.ac.id, ${ }^{3}$ noor.ahsin@umk.ac.id
}

\section{POLA ASUH ORANG TUA DALAM PEMBENTUKAN KARAKTER KEPEDULIAN SOSIAL ANAK SAAT PANDEMI}

\begin{tabular}{|c|c|}
\hline ARTICLE HISTORY & ABSTRACT \\
\hline $\begin{array}{l}\text { Submitted: } \\
20 \text { Agustus } 2021 \\
20^{\text {th }} \text { August } 2021\end{array}$ & $\begin{array}{l}\text { Abstract: This study aimed to analyze the parenting styles applied by parents in shaping the } \\
\text { character of social care and its obstacles. This research was qualitative research with a case } \\
\text { study approach conducted in Desa Ngliron, Kecamatan Randublatung, Kabupaten Blora. The } \\
\text { research subjects were parents and children. Data collection techniques were in the form of } \\
\text { observation, interviews, documentation, and notes. Interviews were conducted with parents } \\
\text { who applied parenting, children, and the community. Data analysis techniques used data } \\
\text { collection, data reduction, data presentation, and drawing conclusions. The results showed that } \\
\text { parents in Desa Ngliron applied democratic and permissive parenting in shaping the character } \\
\text { of social care for the majority of children. The parents applied democratic parenting to } \\
\text { children by providing understanding, habituation, exemplary, and spontaneous activities, so } \\
\text { that children had a character of social care such as being polite, friendly, sharing, and helping } \\
\text { others. Parents who applied permissive parenting tended to pay less attention to their children } \\
\text { and did not apply rules, which made them aggressive and selfish. There were obstacles faced } \\
\text { by parents in shaping the character of social care for children, namely parents' busyness, lack } \\
\text { of parental understanding, children's character, and technology. }\end{array}$ \\
\hline
\end{tabular}

Accepted:

10 Oktober 2021

$10^{\text {th }}$ October 2021

Keywords: parenting patterns, character, social care

\begin{abstract}
Abstrak: Penelitian ini bertujuan untuk menganalisis pola asuh yang diterapkan orang tua dalam membentuk karakter kepedulian sosial dan kendalanya. Penelitian ini merupakan penelitian kualitatif dengan pendekatan studi kasus yang dilaksanakan di Desa Ngliron, Kecamatan Randublatung, Kabupaten Blora. Subjek penelitian adalah orang tua dan anak. Teknik pengumpulan data berupa observasi, wawancara, dokumentasi, dan pencatatan. Wawancara dilakukan dengan orang tua anak yang menerapkan pengasuhan, anak, dan masyarakat. Teknik analisis data menggunakan pengumpulan data, reduksi data, penyajian data, dan penarikan kesimpulan. Hasil penelitian menunjukkan bahwa orang tua di Desa Ngliron dalam membentuk karakter kepedulian sosial pada anak mayoritas menerapkan pola asuh demokratis dan permisif. Orang tua menerapkan pola asuh demokratis kepada anak dengan memberikan pemahaman, pembiasaan, keteladanan, dan kegiatan spontan, sehingga anak memiliki karakter kepedulian sosial sopan santun, ramah, berbagi, dan membantu orang lain. Orang tua yang menerapkan pola asuh permisif cenderung kurang memberikan perhatian yang maksimal terhadap anak dan tidak menerapkan aturan sehingga membuat anak bersikap agresif dan egois. Adapun kendala yang dihadapi orang tua dalam membentuk karakter kepedulian sosial pada anak berupa kesibukan orang tua, kurangnya pemahaman orang tua, karakter anak, dan teknologi.
\end{abstract}

Kata Kunci: pola asuh orang tua, karakter, kepedulian sosial

28 Oktober 2021

$28^{\text {th }}$ October 2021

\section{CITATION}

Hasanah, S. R., Ristiyani. R., \& Ahsin, M. N. (2021). Parenting Styles in Shaping the Children's Social Care Character during the Pandemic. Primary: Jurnal Pendidikan $\begin{array}{lllll}\text { Guru Sekolah Dasar, } 10 \text { (5), 1327-1337. DOI: } & \end{array}$ http://dx.doi.org/10.33578/jpfkip.v10i5.8164. 


\section{PENDAHULUAN}

Pendidikan memiliki peranan yang sangat penting dalam mengembangkan sumber daya manusia dan membentuk kepribadian bangsa. Menurut UU Nomor 20 Tahun 2003 pasal 1 Tentang Sistem Pendidikan Nasional yang menyatakan bahwa pendidikan adalah usaha sadar dan terencana untuk mewujudkan suasana belajar dan proses pembelajaran agar peserta didik secara aktif mengembangkan potensi dirinya untuk memiliki kekuatan spiritual, keagamaan, pengendalian diri, kepribadian, kecerdasan, akhlak mulia, serta keterampilan yang diperlukan dirinya, masyarakat, bangsa, dan negara. Mencermati tujuan pendidikan di Indonesia tersebut, maka masyarakat saat ini bukan hanya dituntut untuk memiliki kecerdasan intelektual tetapi juga harus berkarakter.

Wibowo (2016:12) menyatakan bahwa karakter adalah serangkaian sikap, perilaku, motivasi, keterampilan, watak, tabiat, akhlak, atau kepribadian seseorang yang terbentuk dari internalisasi berbagai kebijakan diyakini dan digunakan sebagai landasan untuk cara pandang, berpikir, bersikap, dan bertindak. Karakter dapat dibentuk melalui pendidikan karakter. Pemerintah menyadari pentingnya pendidikan karakter dengan mengintegrasikan ke dalam Kurikulum 2013. Adanya perubahan dari Kurikulum Tingkat Satuan Pendidikan (KTSP) menjadi Kurikulum 2013 diharapkan mampu membentuk insan yang cerdas baik dari segi spiritual, intelektual, maupun emosional.

Menurut Kementerian Pendidikan Nasional Nasional (Samani dan Hariyanto, 2017:19), pendidikan karakter harus berlangsung pada pendidikan formal, nonformal, dan informal. Pendidikan karakter dapat dilakukan dengan pendidikan informal yang dilaksanakan oleh orang tua dalam lingkup keluarga. Keluarga menjadi tempat utama dan pertama bagi anak dalam memperoleh pendidikan serta berinteraksi dengan orang lain. Sejalan dengan pendapat Ki
Hajar Dewantara (Shochib, 2018:10) yang menyatakan bahwa keluarga merupakan pusat pendidikan yang pertama dan terpenting karena keluarga selalu memengaruhi pertumbuhan budi pekerti pada tiap-tiap manusia.

Orang tua memegang peranan yang sangat penting dalam mendidik dan membentuk karakter anak. Anak cenderung meniru dan menerima segala bentuk yang dilihatnya terutama tingkah laku orang tua. Orang tua sebagai contoh utama bagi anak dalam menjalankan kehidupan di masyarakat diharapkan mampu menjadi teladan dan memberikan contoh yang baik bagi anak. Pola asuh yang diterapkan orang tua memiliki pengaruh yang cukup besar terhadap perkembangan anak. Anisah (2017:72) mengemukakan bahwa pola asuh merupakan sejumlah model atau bentuk perubahan ekspresi dari orang tua yang dapat mempengaruhi potensi genetik yang melekat pada diri indvidu dalam upaya memelihara, merawat, membimbing, membina, dan mendidik anak-anaknya baik yang masih kecil ataupun yang belum dewasa agar menjadi orang dewasa yang mandiri di kemudian hari.

Gerungan (Setiyaningrum, 2017:17) mengemukakan bahwa terdapat tiga jenis yang dapat diterapkan oleh orang tua, yakni pola asuh demokratis, otoriter, dan permisif. Beberapa jenis pola asuh pasti memiliki kecenderungan perbedaan yang menonjol dalam pelaksanaanya. Bentuk pola asuh demokratis merupakan bentuk pola asuh dimana orang tua memberikan kekebasan kepada anak untuk berkreasi dengan adanya batasan dari orang tua, hal ini sangat berbeda dengan pola asuh otoriter dimana orang tua dalam menerapkan pengasuhan bersifat pemaksaan, keras, dan kaku dengan berbagai aturan yang harus ditaati oleh anak. Adapun pola asuh permisif, orang tua dalam memberikan pengasuhan bersikap cuek terhadap anak.

Pada Desember 2019 teridentifikasi 
sebuah virus baru yaitu Coronavirus 2019 (Covid-19) yang pertama kali ditemukan di Wuhan, China. Menurut Supriatna (2020:558), penyakit Coronavirus 2019 (Covid-19) adalah penyakit menular yang disebabkan oleh sindrom pernapasan akut coronavirus 2 (SARS-CoV-2). Gejala umum dari penyakit ini antara lain demam, batuk, sesak napas, nyeri otot, produksi dahak, diare, sakit tenggorokan, kehilangan bau, dan sakit perut. Pada tanggal 4 April 2020, World Health Organization (WHO) menetapkan status pandemi global Covid-19 setelah virus berbahaya ini menyebar ke sebagian besar wilayah dunia. Adanya pandemi ini mengakibatkan lumpuhnya beberapa sector kehidupan diantaranya sektor ekonomi, sosial, dan pendidikan. Banyak perusahaan yang melakukan PHK besarbesaran agar kegiatan produksi tetap berjalan. Pemerintah mengeluarkan kebijakan yang berisi bahwa semua kegiatan bekerja, beribadah, dan sekolah dilaksanakan di rumah guna untuk memutus rantai penyebaran Covid19.

Hakikat manusia sebagai makhluk
sosial senantiasa berhubungan dan membutuhkan orang lain dalam menjalankan kehidupan sehari-hari. Keadaan ini menuntut manusia untuk hidup berdampingan dengan orang lain. Pandemi Covid-19 menyebabkan banyak masyarakat yang kehilangan pekerjaan, maka perlu dipelihara karakter kepedulian sosial di masyarakat sehingga tercipta keadaan yang rukun, damai, dan sejahtera. Kemendiknas (dalam Hidayati, dkk., 2019:20) menyatakan bahwa peduli sosial merupakan sikap dan tindakan selalu ingin memberi bantuan pada orang lain dan masyarakat yang membutuhkan. Peduli sosial termasuk salah satu nilai karakter yang bersumber dari agama, Pancasila, budaya, serta tujuan pendidikan nasional. Karakter peduli sosial dapat ditanamkan dalam lingkungan keluarga seperti halnya membantu membersihkan rumah, mencuci piring, mengambilkan barang, dan lain sebagainya.

Para penduduk di Desa Ngliron sebagian besar bekerja sebagai petani, pedagang, dan wiraswasta. Ketika menjalankan aktivitas sehari-hari, orang tua cenderung fokus terhadap kegiatannya sehingga mengabaikan untuk menanamkan dan membentuk karakter peduli sosial pada anak. Adanya pandemi Covid-19 menjadi momentum yang tepat bagi orang tua untuk menanamkan dan membentuk karakter peduli sosial pada anak. Salah satunya adalah dengan cara mengajak anak untuk ikut merasakan penderitaan yang tengah dialami oleh orang lain yang terkena dampak wabah Covid-19. Sebelum adanya penyebaran wabah ini, sebagian besar orang tua menyerahkan seluruh kegiatan pendidikan maupun pembentukan karakter anak kepada guru di sekolah.

Masyarakat masih menjalankan kegiatan seperti biasa tetapi kegiatan belajar dilaksanakan di rumah masing-masing. Banyak anak yang beranggapan bahwa belajar di rumah sama halnya liburan sehingga sangat diperlukan peran orang tua dalam mendidik anak. Kurangnya perhatian dan rendahnya kesabaran orang tua dalam mendidik anak sehingga tercipta kondisi yang kurang nyaman untuk belajar anak. Kondisi seperti ini membuat anak lebih memilih untuk pergi bermain. Perlunya orang tua menanamkan karakter peduli sosial pada anak untuk membuat anak menjadi pribadi yang mandiri dan mudah bersosialisasi di lingkungan masyarakat, hal ini sejalan dengan pendapat Hayatun (2020:779) menyatakan bahwa anak yang mempunyai kemampuan sosial yang baik akan membuat anak dengan mudah menyesuaikan diri dengan baik terhadap lingkungan hidupnya dapat menikmati masa kecilnya dan mampu menjadi orang dewasa dengan kemampuan adaptasi yang baik.

Observasi telah dilakukan pada hari Kamis, 30 April 2020 di Desa Ngliron yang bertepatan di halaman rumah Ibu DN. Hasil observasi menunjukkan bahwa sikap peduli sosial pada anak usia 7-9 tahun masih tergolong rendah. Hal ini dapat dilihat ketika anak bermain bersama terdapat anak yang 
masih sering menjahili teman. Kejahilan yang dilakukan berupa mengambil mainan maupun mengganggu teman saat belajar. Kejahilan tersebut kemudian berubah menjadi saling menarik baju sehingga menyebabkan pertengkaran antar anak. Belum adanya kesadaran untuk meminta maaf sehingga kejadian yang sama sering terulang dan anak menganggap kejadian tersebut sebagai hal yang biasa. Karakter peduli sosial perlu ditanamkan sejak dini pada anak agar kejadian seperti ini yang terjadi sewaktu kanak-kanak tidak terbawa hingga dewasa.

Wawancara yang telah dilakukan dengan salah satu orang tua anak bernama Ibu DN yang bekerja sebagai seorang guru SD mendapatkan hasil bahwa orang tua membuat peraturan yang harus dipatuhi oleh anak baik secara lisan maupun tulisan. Orang tua selama pandemi memiliki waktu khusus untuk mendampingi dan menanyakan keseharian anak. Orang tua memberikan penjelasan kepada anak bahwa perbuatan baik akan membuat memiliki banyak teman, sedangkan perbuatan buruk akan menyebabkan teman bermain menjadi berkurang. Orang tua juga memberikan teguran dan memarahi anak ketika melakukan kesalahan yang sama. Salah satu wujud dari kasih sayang orang tua yaitu selalu memberikan hadiah dan pujian ketika anak memperoleh prestasi di sekolah. Semua hal yang dilakukan oleh orang tua tersebut bertujuan untuk membentuk karakter anak sejak dini. Hayatun (2020:779) menyatakan bahwa anak yang mempunyai kemampuan sosial yang baik akan membuat anak dengan mudah menyesuaikan diri dengan baik terhadap lingkungan hidupnya dapat menikmati masa kecilnya dan mampu menjadi orang dewasa dengan kemampuan adaptasi yang baik.

Hasil penelitian yang dilakukan oleh Uswatun Hasanah (2016) yang berjudul "Pola Asuh Orang Tua dalam Membentuk Karakter Anak" mendapatkan hasil bahwa pola asuh orang tua dapat mempengaruhi dan membentuk karakter anak secara signifikan melalui berbagai macam hal yang mereka lakukan. Solusi atau pola asuh yang terbaik dalam pembentukan karakter anak adalah tipe pola asuh otoritatif (demokratis). Pola asuh ini bercirikan orang tua yang cenderung menganggap anak sederajat dengan hak dan kewajiban anak dibanding dirinya. Berdasarkan uraian tersebut, peneliti tertarik untuk mengkaji lebih dalam mengenai pola asuh orang tua dalam pembentukan karakter kepedulian anak saat pandemi. Adapun masalah yang dikaji dalam penelitian ini akan difokuskan bagaimana peran pola asuh orang tua dalam pembentukan karakter kepedulian sosial anak dan kendala yang dihadapi dalam proses pembentukan karakter.

\section{METODE PENELITIAN}

Penelitian ini merupakan penelitian kualitatif dengan pendekatan studi kasus yang dilaksanakan di Desa Ngliron, Kecamatan Randublatung, Kabupaten Blora. Subjek penelitian yaitu orang tua dan anak. Teknik pengumpulan data yang digunakan meliputi observasi, wawancara, dokumentasi, dan pencatatan. Sumber data dalam penelitian ini diperoleh dari hasil pengamatan langsung di lapangan, dokumentasi, dan wawancara dengan informan. Adapun pelaksanaan wawancara dilakukan dengan orang tua anak yang menerapkan pengasuhan, anak, dan warga. Jenis wawancara yang digunakan wawancara terstruktur dan mendalam.

Peneliti dalam melaksanakan penelitian dengan menggali informasi sebanyak-banyaknya sesuai situasi dan kondisi yang ada di lapangan. Peneliti dalam menganalisis data dengan menggunakan teknik analisis yang digunakan oleh model Miles dan Huberman yaitu model interaktif. Miles dan Huberman (dalam Sugiyono, 2017:133) mengemukakan bahwa aktivitas dalam analisis data kualitatif dapat dilakukan secara interaktif dan berlangsung terus menerus sampai tuntas hingga datanya jenuh. Adapun langkahlangkah analisis data yang dilakukan meliputi pengumpulan data, reduksi data, penyajian 
data, dan penarikan kesimpulan.

Tahap pengumpulan data diperoleh peneliti dari pengamatan dan wawancara dengan informan. Reduksi data dilakukan untuk mengklasifikasikan data yang telah diperoleh dari penelitian di lapangan. Adapun penyajian data dilakukan setelah tahap pengumpulan dan reduksi data dengan teks yang bersifat naratif. Tahapan terakhir berupa penarikan data dengan merangkum semua data yang telah diperoleh kemudian disajikan dalam bentuk deskripsi yang bersifat sementara.

\section{HASIL DAN PEMBAHASAN}

Pendidikan karakter dapat dilaksanakan di keluarga, sekolah, dan masyarakat. Sejalan dengan pendapat Shochib (2010) menyatakan bahwa pendidikan dilaksanakan pada masyarakat, sekolah, dan keluarga sehingga keluarga menjadi salah satu penanggung jawab dala tercapainya tujuan pendidikan. Anak memperoleh pendidikan karakter yang pertama dan utama di lingkungan keluarga. Anak dalam masa sekolah dasar memiliki karakteristik yang suka bermain dan penasaran yang tinggi sehingga keluarga menjadi penentu dalam mengarahkan anak. Tujuan pendidikan dalam keluarga berupa memberikan nilai moral, budaya, dan sikap yang menjadikan anak mampu hidup mandiri dalam lingkungan masyarakat. Salah satu sikap yang sangat diperlukan oleh anak dalam hidup bersosialisasi di masyarakat yaitu perilaku sosial sehingga orang tua memiliki peranan penting dalam membentuk karakter kepedulian sosial pada anak. Penelitian ini dilaksanakan di Desa Ngliron dengan subjek penelitian anak dengan rentang usia 7-9 tahun dan dan orang tua yang menerapkan pengasuhan sabagai informan utama. Informan utama berjumlah 20 orang, 10 anak dan 10 orang tua.

\section{Peran Pola Asuh Orang Tua dalam Pembentukan Karakter Kepedulian Sosial Anak}

Setiap orang tua pasti selalu menginginkan yang terbaik untuk anak-anak mereka. Perasaan inilah yang kemudian mendorong orang tua untuk memilki perilaku tertentu dalam mengasuh anak. Pada masa pandemi Covid-19, pembelajaran anak dilaksanakan secara daring (dalam jaringan) di rumah sehingga orang tua memegang peranan yang sangat penting dalam membimbing, mengasuh, dan mendidik anaknya. Pembentukan karakter yang dapat ditanamkan kepada anak selama pandemi Covid-19 adalah karakter kepedulian sosial. Interpretasi hasil penelitian yang dimaksud oleh penulis disini adalah hasil akhir dari analisis data yang kemudian ditafsirkan dalam bentuk interpretasi data mengenai peran pola asuh orang tua dalam pembentukan karakter kepedulian sosial anak.

Hasil penelitian yang telah dilakukan menunjukkan bahwa pola asuh yang diterapkan orang tua memiliki peranan dalam pembentukan karakter kepedulian sosial anak. Peranan tersebut dapat dilihat dari pola pengasuhan yang diterapkan sehari-hari dalam mendidik dan membimbing anak. Pemilihan pola asuh yang tepat akan memberikan dampak yang positif bagi anak. Hasil dari penelitian ini terungkap beberapa pola asuh yang diterapkan oleh orang tua dalam membentuk karakter kepedulian sosial anak di Desa Ngliron sebagai berikut:

\section{a. Pola Asuh Demokratis}

Pola asuh demokratis merupakan pola asuh dimana orang tua memberikan kebebasan tetapi masih ada pengawasan terhadap anak. Penerapan pola asuh demokratis dapat terlihat dari beberapa jawaban informan kepada peneliti. Peneliti menemukan terdapat 6 dari 10 orang tua yang dijadikan sebagai subjek penelitian menerapkan pola asuh demokratis. Informan Ibu DN yang berusia 39 tahun dan bekerja sebagai guru SD. Informan mengatakan kepada peneliti bahwa informan selama masa pandemi lebih banyak memiliki waktu di rumah untuk mengawasi anak. 
Informan dalam membentuk karakter kepedulian dengan memberikan kebiasaan dan mencontohkan sikap sopan santun, mengajak anak untuk beribadah bersama, menyapa tetangga, berbagi makanan, mengajak anak untuk menjenguk orang sakit, dan membiasakan anak untuk menyapu. Adapun KAZ berusia 7 tahun anak dari ibu DN memiliki karakter kepedulian sosial yang suka menolong, berbagi, ramah, dan mudah bersosialisasi.

Ibu DY berusia 25 tahun seorang ibu rumah tangga dalam memberikan pengasuhan selalu berusaha untuk memberikan pendampingan kepada anak terutama dalam belajar. Informan dalam membentuk karakter kepedulian sosial anak dengan memberikan contoh, mengajarkan untuk sopan santun, tidak menjahili teman, tidak mengejek teman, dan membantu orang lain. Adanya pendampingan dan pengajaran dari orang tua membuat anak memiliki sikap sosial yang. Adapun MFAP berusia 7 tahun anak dari ibu DY memiliki karakter kepedulian sosial yang bersahabat, sopan santun, suka memberi, dan terkadang mengejek teman.

Ibu $\mathrm{S}$ berusia 26 tahun tahun yang bekerja sebagai seorang petani dalam memberikan pengasuhan sebelum berangkat bekerja selalu berusaha untuk memberikan pendampingan terlebih dahulu kepada anak, tetapi ketika bekerja informan membebaskan anak untuk bermain sepuasnya. Informan dalam membentuk karakter kepedulian sosial kepada anak dengan mengajarkan sopan santun, berbagi, menghormati orang lain dengan memberikan contoh. Adapun AAG berusia 7 tahun anak dari ibu $\mathrm{S}$ memiliki karakter kepedulian sosial yang karakter kepedulian sosial yang dimiliki oleh anak yakni suka berbagi, menolong, meniru, agresif, dan bersikap acuh. Anak juga memiliki perilaku yang tidak sosial berupa sering menirukan perkataan kotor yang didapatkan anak ketika bermain bersama orang yang lebih tua.
Ibu SK berusia 30 tahun seorang ibu rumah tangga dalam memberikan pengasuhan selalu berusaha untuk memberikan pengasuhan yang maksimal kepada anak meskipun sibuk dalam mengurus anak kedua yang masih bayi, tetapi adanya nenek yang membantu dalam mengurus anak kedua sehingga dapat membuat informan untuk dapat membagi perhatian secara maksimal kepada kedua anaknya. Informan dalam membentuk karakter kepedulian sosial pada anak dengan memberikan kebiassaan berupa sholat tepat waktu, mencuci piring setelah makan, belajar setelah sholat magrib, dan tidur jam 9 malam. Lingkungan juga membantu informan dalam membentuk karakter kepedulian sosial. Adapun MK berusia 9 tahun anak dari ibu SK memiliki karakter kepedulian sosial yang suka menolong, menjenguk teman yang sakit, dan menaati perintah orang tua.

Ibu SM berusia 28 tahun seorang ibu rumah tangga dalam memberikan pengasuhan dengan memenuhi kebutuhan sebagai penunjang pertumbuhan dan perkembangan anak. Informan sebagai ibu rumah tangga memiliki waktu yang banyak dan maksimal dalam memberikan pendampingan kepada anak. Informan berusaha mengajarkan kepada anak untuk bersikap sopan santun, menghormati, dan membantu orang lain. Informan juga berusaha mendorong anak untuk lebih percaya diri karena anak memiliki karakter yang pemalu. Adapun Adapun AL berusia 7 tahun anak dari ibu SM memiliki karakter kepedulian sosial yang sopan santun, ramah, dan membantu orang lain.

Ibu SM berusia 27 tahun seorang ibu rumah tangga dalam memberikan pengasuhan selalu mencukupi kebutuhan dan mendampingi secara maksimal dengan mengingatkan kewajiban yang harus dilaksanakan oleh anak. Informan dalam membentuk karakter kepedulian anak dengan memberikan contoh, menjelaskan perbuatan baik dan buruk, membiasakan untuk sopan santun, menghormati orang lain, tidak menjahili teman, membantu, sholat tepat waktu, ngaji 
sore, dan belajar. Adapun MIT berusia 7 tahun anak dari ibu SM memiliki karakter kepedulian sosial yang sopan santun dan menolong orang lain.

Orang tua yang menerapkan pola asuh demokratis dengan memberikan perhatian dan bimbingan secara maksimal sehingga menjadikan anak memiliki karakter kepedulian sosial yang tinggi baik di lingkungan keluarga maupun masyarakat. Menurut Hurlock (dalam Adawiah, 2017:35), pola asuh demokratis adalah pola asuh dimana orang tua berusaha untuk menanamkan kedisiplinan dan menghargai kebebasan anak dengan memberikan bimbingan dan pengertian antara orang tua dan anak. Berdasarkan hasil wawancara dan observasi dengan orang tua yang menerapkan pola asuh demokratis memberikan kebiasaan-kebiasaan yang baik sehingga membawa dampak positif terhadap pembentukan karakter kepedulian sosial bagi anak.

Anak dari orang tua yang menerapkan pola asuh demokratis memiliki karakter yang suka berbagi, menolong, sopan santun, ramah, dan membantu orang lain. Helms dan Turner (dalam Lestiawati, 2013:113) mengemukakan bahwa pola perilaku sosial anak dapat dilihat dari empat dimensi yaitu (a) anak dapat bekerjasama (cooperating) dengan teman, (b) anak mampu menghargai (altruism) teman baik menghargai milik, pendapat, hasil karya teman atau kondisi-kondisi yang ada pada teman, (c) anak mampu berbagi (sharing) kepada teman, dan (d) anak mampu membantu (helping other) kepada orang lain. Berdasarkan pola perilaku sosial anak di Desa Ngliron mampu untuk bekerjasama, berbagi, dan membantu kepada teman.

\section{b. Pola Asuh Permisif}

Pola asuh permisif merupakan pola asuh dimana orang tua cuek dan tidak mau terlibat dalam kehidupan anak. Penerapan pola asuh permisif dapat terlihat dari beberapa jawaban informan kepada peneliti. Berdsarkan hasil wawancara dan observasi dengan Ibu UK berusia 30 tahun yang menerapkan pola asuh permisif cenderung memberikan kebebasan, kurang adanya kontrol, dan kurang memberikan pendampingan secara maksimal karena sibuk mengurus anak kedua yang masih bayi. Anak yang kurang mendapatkan perhatian akan berdampak negatif yang menyebabkan anak berbuat sesuka hati dan karakter kepedulian sosial yang rendah. Adapun RS berusia 9 tahun anak dari ibu UK memiliki karakter yang egois, suka membantah, dan agresif.

Informan Ibu $\mathrm{SH}$ berusia 48 tahun seorang petani dalam memberikan pengasuhan selalu berusaha untuk memenuhi kebutuhan ana tetapi hanya untuk yang penting-penting saja. Informan dalam memberikan pendampingan cenderung membebaskan anak ketika bekerja di ladang dan meminta bantuan kepada neneknya untuk mengawasi. Informan dalam membentuk karakter kepedulian sosial anak dengan menjelaskan perbuatan baik dan buruk, memberikan contoh, serta mengajarkan sopan santun, membantu teman, dan tidak menyela perkataan orang lain. Adapun RNL berusia 7 tahun anak dari ibu $\mathrm{SH}$ memiliki karakter kepedulian sosial yang dimiliki oleh anak yakni rendah hati dan mudah bersosialisasi. Anak juga diberikan kewajiban untuk membantu kakak dalam menjaga anaknya.

Informan Ibu $\mathrm{S}$ berusia 39 tahun seorang petani dalam memberikan pengasuhan selalu berusaha untuk memenuhi kebutuhan dan memberikan pendampingan kepada anak. Informan yang bekerja di ladang menjadikan pendampingan berjalan kurang maksimal. Informan sering meninggalkan anak di rumah dan diberi tugas untuk mencuci piring serta menemani nenek. Informan dalam membentuk karakter kepedulian sosial kepada anak dengan mengajarkan sopan santun dan membantu orang lain. Adapun AAB berusia 9 tahun anak dari ibu S memiliki perilaku yang tidak patuh, mudah bersosialisasi, membiarkan teman bertengkar, dan agresif. Perilaku tidak sosial juga diperlihatkan anak ketika membiarkan 
teman bertengkar. Shapiro (dalam Jannah, 2012:7) menyatakan bahwa orang tua yang menerapkan pola permisif berusaha menerima dan mendidik anaknya sebaik mungkin tapi cenderung sangat pasif ketika sampai pada masalah penetapan batas-batas atau menanggapi ketidakpatuhan. Informan hanya menegur anak ketika anak berbuat salah.

Informan Ibu SR berusia 51 tahun seorang petani dalam memberikan pengasuhan dengan mencukupi kebutuhan sehari-hari anak. Informan yang bekerja di ladang menjadikan pendampingan yang diberikan kurang maksimal dan anak cenderung diberikan kekebasan penuh untuk bermain. Informan yang sudah tua setelah bekerja tidak terlalu memperhatikan anak karena lelah dan sibuk mengurusi rumah. Informan dalam membentuk karakter kepedulian sosial dengan berusaha mengajarkan sopan santun, membantu orang lain, dan menyuruh anak untuk memberikan makan sapi. Adapun AK berusia 9 tahun anak dari ibu SR memiliki karakter kepedulian sosial yang perilaku sosial yang dimiliki oleh anak yakni ramah sopan santun, suka menolong, dan agresif.

Orang tua yang menerapkan pola asuh permisif cenderung memberikan kebebasan kepada anak dan kurang memberikan pendampingan secara maksimal kepada anak. Anak yang kurang mendapatkan perhatian dari orang tua cenderung membawa dampak negatif berupa anak berbuat semaunya dan sesuka hati sehingga karakter kepedulian anak rendah. Orang tua yang menerapkan pola asuh permsif tidak terlalu mementingkan terhadap proses pembentukan karakter kepedulian sosial pada anak. Adapun anak dengan orang tua menerapkan pola asuh permisif cenderung tidak memiliki perilaku sosial yang ditunjukkan dari perilaku egois dan agresif.

Berdasarkan uraian di atas, maka dapat disimpulkan bahwa orang tua yang menerapkan pola asuh demokratis berusaha untuk memberikan pendampingan secara maksimal kepada anak, sedangkan orang tua yang menerapkan pola asuh permisif berusaha untuk memberikan pendampingan tetapi cenderung cuek dan membebaskan anak untuk berbuat semaunya. Adapun faktor-faktor yang mempengaruhi dalam pemilihan pola asuh yang diterapkan orang tua yaitu usia, pendidikan, dan pekerjaan. Orang tua dalam membentuk karakter kepedulian sosial dengan strategi memberikan pemahaman, keteladanan, pembiasaan, dan kegiatan spontan. Pola asuh orang tua sangat berperan dalam pembentukan karakter kepedulian sosial anak.

\section{Kendala yang dihadapi Orang Tua dalam Pembentukan Karakter Kepedulian Sosial Anak \\ Pola asuh orang tua adalah pola} perilaku orang tua yang diterapkan pada anak yang bersifat relatif dan berubah-ubah dari waktu ke waktu sesuai kondisi. Pola perilaku yang diterapkan orang tua dapat dirasakan dan berdampak pada anak baik dari segi positif maupun negatif. Cara orang tua dalam membentuk karakter kepedulian sosial anak tentu tidak dapat terlepas dari pandangan dan pemahaman orang tua dalam pembentukan karakter. Hasil penelitian ini menunjukkan tentang adanya beberapa kendala yang dihadapi orang tua dalam membentuk karakter kepedulian sosial pada anak sebagai berikut:

\section{a. Kesibukan Orang Tua}

Kesibukan orang tua ternyata menjadi kendala dalam pembentukan karakter kepedulian sosial pada anak. Perhatian orang tua terhadap satu atau dua orang tentu akan berbeda. Orang tua akan lebih cenderung dalam memberikan perhatian dan mendampingi anak yang lebih kecil secara maksimal. Salah seorang informan bernama Ibu UK mengatakan kepada peneliti bahwa informan lebih fokus dalam mengurus anak yang masih bayi. Pernyataan inilah yang menjadikan perhatian kepada anak kurang maksimal. Tugas sekolah anak menjadi kurang terurus karena kurangnya perhatian orang tua dan anak lebih banyak menghabiskan waktu untuk bermain. 
Informan lain bernama Ibu $\mathrm{S}$ mengungkapkan bahwa sebelum berangkat bekerja menemani anak terlebih dahulu, tetapi ketika sudah berangkat bekerja anak akan membiarkan semua aktivitas. Informan yang lebih sibuk bekerja di ladang menyebabkan lebih banyak menghabiskan waktu untuk bekerja sehingga kurang maksimal dalam mengawasi dan mengarahkan anak. Senada dengan Ibu $\mathrm{S}$, informan Ibu $\mathrm{S}$ menjelaskan bahwa sebelum berangkat bekerja, informan berusaha untuk memberikan tugas berupa mencuci piring dan menemani nenek, tetapi anak tidak melakukan tugasnya dan lebih memilih untuk bermain. Beberapa pernyataan yang disampaikan informan tersebut, maka dapat disimpulkan bahwa orang tua yang memiliki kesibukan kurang memperhatikan dan cenderung membiarkan anak.

\section{b. Kurangnya Pemahaman Orang Tua}

Kendala lainnya yang dihadapi orang tua adalah kurangnya pemahaman. Latar belakang usia dan pendidikan mempengaruhi dalam kurangnya pemahaman orang tua. Informan Ibu $\mathrm{SH}$ berusia 48 tahun mengungkapkan bahwa cenderung merasa kesulitan karena kurangnya pemahaman dan lebih mengandalkan guru dalam pembentukan karakter kepedulian sosial anak. Orang tua lebih fokus untuk memenuhi kebutuhan anak. Orang tua dalam memberikan pengarahan dan bimbingan tapi belum secara maksimal.

Senada dengan pernyataan Ibu SH, informan Ibu SR berusia juga mengungkapkan bahwa untuk pembentukan karakter kepedulian sosial lebih mengandalkan guru di sekolah dikarenakan sibuk bekerja dan kurang memahami pendidikan karakter. Berdasarkan pernyataan yang telah disampaikan oleh informan, maka dapat disimpulkan bahwa kendala kurangnya pemahaman terhadap karakter kepedulian sosial dipengaruhi oleh usia dan tingkat pendidikan orang tua.

\section{c. Karakter Anak}

Karakter anak juga menjadi kendala bagi orang tua dalam membentuk karakter kepedulian sosial. Peneliti menemukan bahwa orang tua yang mengalami kesulitan dalam membentuk karakter kepedulian sosial pada anak yang berkarakter suka membantah, pemilih teman, bandel, susah dinasehati, pemalu, dan mudah tersinggung. Ibu DN anak suka membantah. Ibu DY anak suka pilih-pilih teman. Ibu SK anak bandel. Ibu SM anak pemalu. Ibu SM anak mudah tersinggung. Menurut Putri, dkk. (2017:3), anak yang merasa kurang percaya diri akan menyebabkan anak tidak dapat berinteraksi dengan baik dilingkungannya sehingga anak akan dikucilkan, dijauhi, dan kesulitan untuk mendapatkan teman sebaya dalam bermain maupun kelompok. Hal ini mengakibatkan pembentukan karakter kepedulian sosial anak sulit tercapai.

\section{d. Teknologi}

Pada saat ini anak sekolah dasar tengah melakukan pembelajaran secara daring melalui media hp. Adapun kendala yang dihadapi orang tua berupa anak menjadi egois dengan merebut hp karena lebih menyukai permainan yang ada di hp. Informan Ibu DN menjelaskan bahwa Anak yang lebih banyak menghabiskan waktu dengan bermain hp mengalami kesulitan dalam bersosialisasi. Informan Ibu $\mathrm{S}$ mengungkapkan bahwa anak sering mengabaikan perintah orang tua untuk mencuci piring dan menemani neneknya, sehingga membuat orang tua merasa jengkel. Chusna (2017:320) menyatakan bahwa hal yang harus diwaspadai ketika anak bermain gadget yaitu anak cenderung bersikap membela diri dan marah ketika ada upaya untuk mengurangi atau menghentikan penggunaan gadget. Peran orang tua sangat diperlukan untuk mengawasi dan membatasi waktu anak sehingga pembentukan karakter kepedulian sosial pada anak bisa tercapai.

Kendala yang dihadapi orang tua saling berkaitan antara satu dengan yang lainnya. Orang tua yang sibuk dengan kegiatan dan pekerjaan akan membuat anak kurang mendapatkan pendampingan secara maksimal sehingga anak cenderung berbuat semaunya dan menyebabkan karakter anak menjadi 
kurang terarah. Orang tua yang kurang memiliki pemahaman terhadap pentingnya karakter kepedulian sosial mengalami kesulitan dalam pembentukan karakter anak. Anak di Desa Ngliron memiliki karakter yang berbeda-beda, yakni suka membantah, pemilih teman, bandel, susah dinasehati, pemalu, mudah tersinggung, dan pendiam. Teknologi berupa hp juga ikut andil terhadap kendala yang dihadapi orang tua dalam pembentukan karakter kepedulian sosial anak.

\section{SIMPULAN}

Hasil penelitian yang telah dilakukan menunjukkan bahwa mayoritas orang tua di Desa Ngliron menerapkan pola asuh demokratis dalam membentuk karakter kepedulian sosial pada anak. Adanya pola asuh demokratis memberikan peranan yang positif bagi anak dalam pembentukan karakter kepedulian sosial dimana orang tua berusaha untuk memberikan pendampingan, perhatian, dan bimbingan yang maksimal. Anak dengan orang tua yang menerapkan pola asuh demokratis memiliki sikap sosial yang suka menolong, berbagi, sopan santun, dan membantu orang lain. Orang tua yang menerapkan pola asuh permisif kurang memberikan perhatian dan tidak menerapkan aturan sehingga anak memiliki sikap sosial yang agresif dan egois. Orang tua dalam membentuk karakter kepedulian sosial dengan memberikan pemahaman, pembiasaan, keteladanan, dan kegiatan spontan.

Orang tua dalam memberikan pengasuhan kepada anak mengalami beberapa kendala yakni kesibukan orang tua, kurangnya pemahaman orang tua, karakter anak, dan teknologi. Keluarga yang berada pada tingkat ekonomi rendah akan menuntut orang tua untuk bekerja lebih giat sehingga orang tua lebih sibuk bekerja yang menyebabkan waktu untuk mendampingi anak kurang maksimal. Orang tua yang masih muda memiliki pemahaman dan pengetahuan yang lebih luas dibandingkan dengan orang tua yang sudah tua. Ana yang memiliki karakter pemalu mengalami kesulitan dalam bersosialisasi dengan lingkungan sekitar. Anak yang lebih suka bermain hp menyebabkan anak bersikap acuh terhadap lingkungan dan mengabaikan perintah dari orang tua.

\section{DAFTAR PUSTAKA}

Adawiah, R. (2017). Pola Asuh Orang Tua dan Implikasinya terhadap Pendidikan Anak: Studi pada Masyarakat Dayak di Kecamatan Halong Kabupaten Balangan. Jurnal Pendidikan Kewarganegaraan, 7 (1), 33-48.

Anisah, A. S. (2017). Pola asuh orang tua dan implikasinya terhadap pembentukan karakter anak. Jurnal Pendidikan UNIGA, 5(1), 70-84

Chusna, P. A. (2017). Pengaruh media gadget pada perkembangan karakter anak. Dinamika Penelitian: Media Komunikasi Penelitian Sosial Keagamaan, 17(2), 315-330.

Hasanah, U. (2016). Pola asuh orangtua dalam membentuk karakter anak. Jurnal Elementary, 2 (2), 72-82.

Hayatun, M., Nurhasanah, \& Siti, S. (2020). Pengaruh Penggunaan Metode Role Playing terhadap Perkembangan Sosial Emosional pada Anak Sekolah. Primary: Jurnal Pendidikan Guru Sekolah Dasar. 9 (6), 776-787.

Hidayati, T. U. (2019). Pengaruh Kecerdasan Emosional terhadap Sikap Peduli Sosial Siswa di SMP NEGERI 1 PALEMBANG. Bhineka Tunggal Ika: Kajian Teori dan Praktik Pendidikan PKn, 6(1), 17-36.

Jannah, H. (2012). Bentuk pola asuh orang tua dalam menanamkan perilaku moral pada anak usia di kecamatan ampek angkek. Jurnal Ilmiah Pesona PAUD, 1(2) , 1-10.

Lestiawati, I. M. (2013). Pengaruh pola asuh orang tua terhadap kemampuan sosial anak usia 6-7 tahun. Jurnal Ilmiah Visi, 8(2), 111-119.

Samani, M., dan Hariyanto. (2017). Konsep 


\section{PRIMARY: JURNAL PENDIDIKAN GURU SEKOLAH DASAR \\ VOLUME 10 NOMOR 5 OKTOBER 2021 \\ ISSN : 2303-1514 | E-ISSN : 2598-5949 \\ DOI : http://dx.doi.org/10.33578/jpfkip.v10i5.8164 \\ https://primary.ejournal.unri.ac.id/index.php/JPFKIP}

dan Model Pendidikan Karakter.

Bandung: Remaja Rosdakarya

Offset.

Setiyaningrum, E. (2017). Buku Ajar Tumbuh Kembang Anak Usia 0-12 Tahun.

Sidoarjo: Indomedia Pustaka.

Shochib. (2018). Pola Asuh Orang Tua dalam membantu Anak mengembangkan Disiplin Diri. Jakarta: Rineka Citra.

Supriatna, E. (2020). Wabah Corona Virus Disease Covid 19 Dalam Pandangan Islam. SALAM: Jurnal Sosial Dan Budaya Syar-I, 7(6).

Putri, R. B. L., Umari, T., \& Rosmawati, R. Pengaruh Pola Asuh Orang Tua terhadap Perilaku Sosial (Siswa Kelas VII SMP Negeri 8 Pekanbaru) (Doctoral dissertation, Riau University).

Sugiyono. (2017). Metode Penelitian Kualitatif. Bandung: Alfabeta.

Undang-Undang Republik Indonesia No. 20 Th. 2003 tentang Sistem Pendidikan Nasional. (2003). Jakarta.

Wibowo, A. (2016). Manajemen Pendidikan Karakter di Sekolah (Konsep dan Praktik Implementasi). Yogyakarta: Pustaka Pelajar. 